\title{
The effect of green fertilizers on the ecological structure of soil invertebrate communities in an andisol of Southwestern Colombia
}

\author{
María F. Urbano $^{1 *}$, María F. Pantoja ${ }^{2}$, Iván A. Delgado ${ }^{3}$, Paulo C. Cabrera ${ }^{4}$ \& Iván F. Benavides ${ }^{5}$ \\ 1. Universidad de Nariño, Facultad de Ciencias Agrícolas, Pasto, Colombia; mariafernandaurbanoestrada@gmail.com \\ 2. Universidad de Nariño, Facultad de Ciencias Agrícolas, Pasto, Colombia; marpantoja.1996@gmail.com \\ 3. Docente investigador. Universidad de Nariño, Facultad de Ciencias Agrícolas, Pasto, Colombia; \\ ivan.delgado@udenar.edu.co \\ 4. Docente investigador. Universidad de Nariño, Facultad de Ciencias Agrícolas, Pasto, Colombia; \\ paulocabrera28@gmail.com \\ 5. Investigador Grupo de Investigación Agroforestería y Recursos Naturales ARENA - Universidad de Nariño; \\ pipeben@gmail.com \\ * Correspondencia
}

Received 25-IV-2019. C Corrected 15-VII-2019. Accepted 27-IX-2019.

\begin{abstract}
Introduction: Chemical fertilizers for agriculture can negatively affect the communities of soil invertebrates that contribute to nutrient cycling, nutrient availability, soil formation and fertility. As an alternative, previous work has suggested that green fertilizers (fresh tissue from plants) are effective to preserve soil fertility, without affecting the ecological properties of invertebrate communities. Objective: This work aimed to evaluate how green fertilizers affect the ecological structure of an invertebrate community in an andisol from Southwestern Colombia. Methods: Fresh leaves from seven plant species locally sown and grown in March 2018 were used as the fertilizers by incorporating and mixing them with the soil in 24 experimental subplots. After 45 days of incorporation, the abundance, richness, biomass and diversity of soil invertebrates were measured in three replicate soil cores per subplot and at three depths. Results: Comparing against a control treatment with no fertilization, the richness and abundance of soil invertebrates were up to 14-fold higher in treatments with Alnus jorullensis and Brassica napus, and up to 5-fold higher in treatments with Vicia sativa, Lupinus mutabilis, Plantago lanceolata and Medicago sativa. Diversity indices showed a shift from high dominance by one or a few invertebrate families in the control treatment, to a high diversity and greater evenness in the $\mathrm{A}$. jorullensis, $P$. lanceolata and $M$. sativa treatments. Biomass was negatively correlated with richness and abundance, suggesting a possible ecological trade-off worth to evaluate in further research. Conclusions: In general, our results demonstrate that the application of green fertilizers in this Andean environment can significantly improve the ecological status of soil invertebrate communities. These communities ultimately provide the ecological functions for soil dynamics; thus, agroecology practices should consider them as a valuable alternative to balance production and conservation.
\end{abstract}

Key words: soil, green manures, macrofauna, diversity, abundance, richness.

Urbano, M. F., Pantoja, M. F., Delgado, I. A., Cabrera, P. C., \& Benavides, I. F. (2019). The effect of green fertilizers on the ecological structure of soil invertebrate communities in an andisol of Southwestern Colombia. Revista de Biología Tropical, 67(6), 1394-1405.

The soil is a fundamental component of natural and social systems, fulfilling keystone functions of biological nature such as feeding, filtering and biomechanical support. It houses various animal species responsible of the metabolic activity that are essential for its formation, functioning and fertility (Gupta $\&$ Malik, 1996). Soil organisms are the main agents of the nutrient cycles and provide essential ecosystem services for the sustainability of 
ecosystems, such as regulating the dynamics of organic matter (FAO, 2015).

The accelerated and sometimes irreversible degradation of soils is one of the greatest risks for humanity. Blum (2000) defines this degradation as an unbalance of soil functions, which can cause physical, chemical, and biological damage, even in some cases its destruction. In Colombia, $93 \%$ of the agricultural soils are degraded by some level of erosion, $4.6 \%$ are under severe erosion, and only $7 \%$ are in good conditions (IDEAM, 2015). As an alternative practice to conserve soils properties without reducing their fertility, green manures have emerged as an agroecological technology which have proven to improve biological soil properties such as the diversity and abundance of soil invertebrates, keystone agents of soil functioning. This is of particular importance in agriculture lands owned by low-income farmers (Labrador, 2001).

Soil invertebrates are involved in different processes that allow soil functioning and its co-functioning with plants, water and the atmosphere. Much of these invertebrate species are function-specific or belong to functional groups that perform unique or a few specific functions (Stork \& Eggleton, 1992; Julca, Meneses, Blas, \& Bello, 2006; Culliney, 2013). Therefore, higher diversities of invertebrate species and/ or its functional groups fulfill larger varieties of the several soil functions required to maintain nutrient cycling, regulation of the organic matter dynamics, carbon sequestration, transformation of the structural soil constituents, among others (Abi-Saab, 2012).

By reducing the use of traditional soil fertilizers and adopting agroecological management practices for agricultural systems can result in the colonization and/or proliferation of beneficial invertebrates for the soil (Mäder et al., 2002). The incorporation of green fertilizers is considered an agroecological practice that can improve the structure, diversity and composition of the invertebrate community associated with the soil (Guzmán \& Alonso, 2008). The decomposition process of green fertilizers usually offers better environmental and nutrient conditions than traditional fertilizers, and frequently favors the colonization by diverse invertebrate species (Villalobos et al., 2000).

The aim of this research was to evaluate the effect of the application of seven green fertilizers on some biological properties of the invertebrate community in an andisol of the Nariño region in Southwestern Colombia. Due to their high fertility, the soils in this Andean region are mainly used for agricultural purposes; however, they have been severely affected by intensive cropping of potatoes, onions, peas, and other high-altitude vegetables that require chemical fertilizing for good production (Bautista, Chavarro, Cáceres, \& Buitrago, 2017). This, added to the fact of low economic incomes for farmers, encourage the constant search for profitable and sustainable agroecological solutions.

\section{MATERIALS \& METHODS}

Location: This research was conducted at the farm "El Fondo", $13 \mathrm{~km}$ far from Pasto city in the Southwestern Colombian Andes, close to the border with Ecuador. The study site locates at coordinates $\left(77^{\circ} 19^{\prime} 57.80^{\prime \prime} \mathrm{W} \& 1^{\circ} 16^{\prime} 21.09^{\prime \prime}\right.$ $\mathrm{N})$, and at $2700 \mathrm{msnm}$ of altitude. The location has a temperature of $15{ }^{\circ} \mathrm{C}$, annual rainfall of $1527 \mathrm{~mm}$ and relative humidity of $70 \%$, has a climate is considered Dfb according to the climatic classification of Köppen-Geiger (Climate-Data.org, 2018), corresponds to a living zone according to holdridge to humid montane forest (bh-M) (Holdridge, 1996) and The soils belong to Typic Melanocryands, Lithic Melanocryands and Miscellaneous Rocky (MEBf), formed from thick deposits and thin volcanic ash over andesites. These soils have good drainage and are moderately deep to shallow (IGAC, 2004).

Experimental design: Seven species of native plants were chosen as the green fertilizers, following Prager, Sanclemente, Sánchez, Gallego, and Sánchez (2012), who suggests that these species should belong to different 
families, including legumes, grasses and composites. Thus, the experiment comprised seven fertilization treatments: T0: Absolute Control (no fertilization); T1: Vicia sativa L.; T2: Plantago lanceolata L.; T3: Medicago sativa L.; T4: Trifolium repens L.; T5: Brassica napus L.; T6: Lupinus mutabilis Sweet and T7: Alnus jorullensis Humboldt, Bonpland \& Kunth.

These treatments were organized in a 15 $\times 50 \mathrm{~m}$ plot $\left(750 \mathrm{~m}^{2}\right)$ following a Randomized Complete Block design (RCB), with three replicates per treatment (24 subplots of 21.6 $\mathrm{m}^{2}$ each). The spatial distance between treatments was fixed to $0.27 \mathrm{~m}$ and between blocks to $1.4 \mathrm{~m}$. Since the pot had a slope of $20 \%$, the three replicates per treatment were organized together in lines following that slope. This avoided the run-off on rainy days to mix the treatments, the experimental area commonly suffers from actions of the implementation of livestock production systems.

Sowing and incorporation of the green fertilizers: The plant seeds were obtained from Agrosemillas («Agrosemillas | Importadora y comercializadora en Medellín», s.f.), which assures germination percentages from 90 to $99 \%$. The following seed amounts were sown for each species: V. sativa: $166.6 \mathrm{~g}$, P. lanceolata: $166.16 \mathrm{~g}$, M. sativa: $154 \mathrm{~g}$, T. repens: 151 g, B. napus: $141.6 \mathrm{~g}$ and L. mutabilis: 661.6 g. On March 15, 2018 the seeds were broadcast sown at high densities in the 24 subplots (Carreón \& Martínez, 2016). After 60 days the sowing, $8 \mathrm{~kg}$ of leaves each of species were cut and mixed with the surface soil layer $(0-10 \mathrm{~cm})$ (Morán et al., 2012). From the trees near the plot, forage was collected, cutting the $A$. jorullensis leaves with stainless scissors and placing them in plastic bags, to be transferred to the experimental plot.

Sampling of soil invertebrates: After 45 days of the incorporation of the green fertilizers, a sampling of soil invertebrates was carried out using the TSBF methodology (Tropical Soil Biology and Fertility) described by Anderson and Ingram (1993). Three sampling points in each of the 24 experimental subplots were randomly located and a core of $0.25 \times 0.25 \times$ $0.30 \mathrm{~m}$ (volume $=0.0625 \mathrm{~m}^{3}$ ) was obtained from each one. Three subsamples were taken from each core $(0-10 \mathrm{~cm}, 10-20 \mathrm{~cm}$, and 20-30 $\mathrm{cm}$ deep) and all the arthropods and annelids were manually extracted. These three depths were considered as an additional factor for the experimental design. The arthropods were preserved in $70 \%$ alcohol and the annelids in $5 \%$ formalin. All the samples were transported to the Entomology Laboratory of the University of Nariño who use the taxonomic keys Doreste (1984), Fauchald (1977), Triplehorn and Johnson (2004) were identified at the family level using a Nikon smz 646 stereoscope, in each sampling carried out, the biomass was established, calculating the grams of fresh weight of the individuals per $\mathrm{m}^{2}$ in each of the treatments, by using a precision balance.

Data analysis: For each sample we measured the family richness, the abundance of individuals, biomass. A curve of family accumulation was built and used to assess the efficiency of the sampling effort. Jack 1 and Bootstrap statistics were estimated using the Estimate $\mathrm{S}$ version 9.1.0 program (Colwell, 2006).

The Simpson (D) and Shannon-Wiener (H) diversity indexes (Moreno, 2001) were estimated using software Past ver 3.20. Two-way analyses of variance were performed to evaluate the effect of the green fertilizer, soil depth and their interaction (independent variables), on the family richness, abundance, biomass and diversity of soil invertebrates (dependent variables). Tukey post-hoc tests with a level of significance of 0.05 were performed for each variable in order to locate the differences inferred by the analyses of variance. Finally, a type II linear regression (Reduced Major Axis) (Sokal \& Rohlf, 1995) was fitted to understand the relationship between the abundance of individuals and the family richness. These analyzes were done using software R-studio 1.0.153 (RStudio Team, 2017). 


\section{RESULTS}

Abundance: The abundance of individuals for the whole experimental plot was 9488 . A. jorullensis had the highest abundance (2 080 individuals) and Control the lowest (512 individuals). Table 1 shows the total abundance for each invertebrate family under each green fertilizer treatment. The analysis of variance showed a significant effect of depth $(\mathrm{F}=3.08$, $\mathrm{P}<0.05)$ and a marginally significant effect of the green fertilizers $(\mathrm{F}=2.08, \mathrm{P}=0.06)$ on the mean abundance of individuals. Application of green fertilizers affected this abundance in a different way for each soil depth, showing higher average values in $0-10 \mathrm{~cm}$ in the $A$. jorullensis, B. napus and L. mutabilis treatments (384, 309 and 234 individuals, respectively) (Fig. 1). The Control treatment showed the lowest mean abundance, with 26 individuals. However, the largest variation in abundance occurred mainly in the surface soil layer $(0-10 \mathrm{~cm})$. This was conspicuous in the A. jorullensis treatment, which had a 14-fold higher mean abundance than the Control at this depth.

Family richness: Although the family accumulation curves did not reach a stabilized asymptote, the efficiency in the sampling effort was around $50 \%$, which is considered satisfactory (Fig. 2) (Chao, Colwell, Lin, \& Gotelli, 2009). The analysis of variance showed a significant effect of green fertilizers $(\mathrm{F}=3.62$, $\mathrm{P}<0.01)$, the soil depth $(\mathrm{F}=8.77, \mathrm{P}<0.001)$ and their interaction $(\mathrm{F}=2.02, \mathrm{P}<0.05)$ on the richness of invertebrate families. Green fertilizers increased the family richness differentially for each soil depth compared to Control treatment (Fig. 3). The treatments with the highest richness were $A$. jorullensis and $B$. napus; however, similarly to the results for invertebrate abundance, these variations occurred more intensely in the surface soil layer $(0-10 \mathrm{~cm})$. At greater depths $(10-20$ and $20-30 \mathrm{~cm})$ the family richness also increased in some treatments, but with smaller effect sizes than in the surface soil.

Our data also showed differences in family composition among fertilization treatments, not only due to families with higher abundances, but also because invertebrate families unique for some treatments or seldomly shared among them. Very clear examples of unique treatment-invertebrate associations were M. sativa-Miridae, A. jorullensis-Tipulidae,



Fig. 1. Comparison of mean abundances of soil invertebrates among each green fertilizer treatment and each soil depth at the experimental plot El Fondo in Southwestern Colombia. Vertical bars represent the standard error of the mean and different letters show significant differences according to the post-hoc Tukey test $(\mathrm{P}<0.05)$. 


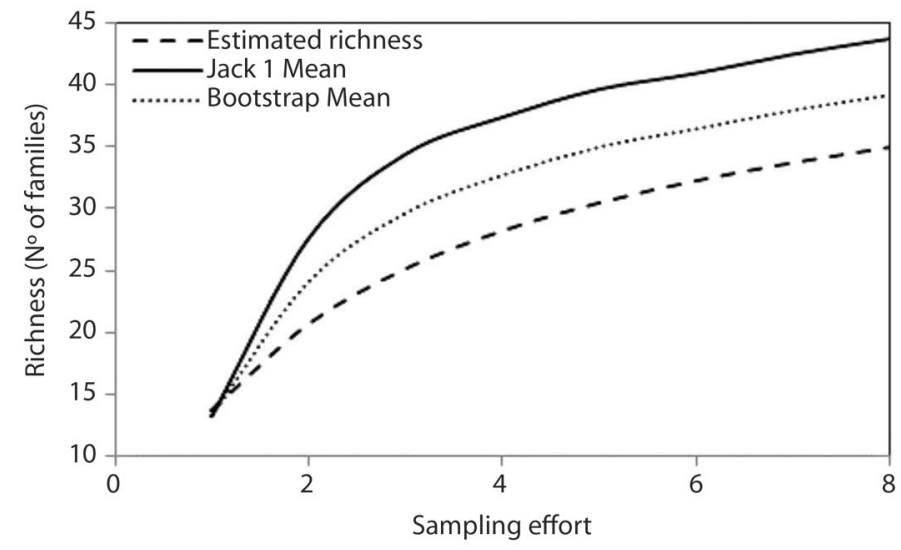

Fig. 2. Accumulation curve of soil invertebrate families at the experimental plot El Fondo in Southwestern Colombia. Statistical estimators of richness are shown as means for all the experimental subplots (Estimated richness, Jack 1 Mean, Bootstrap Mean).

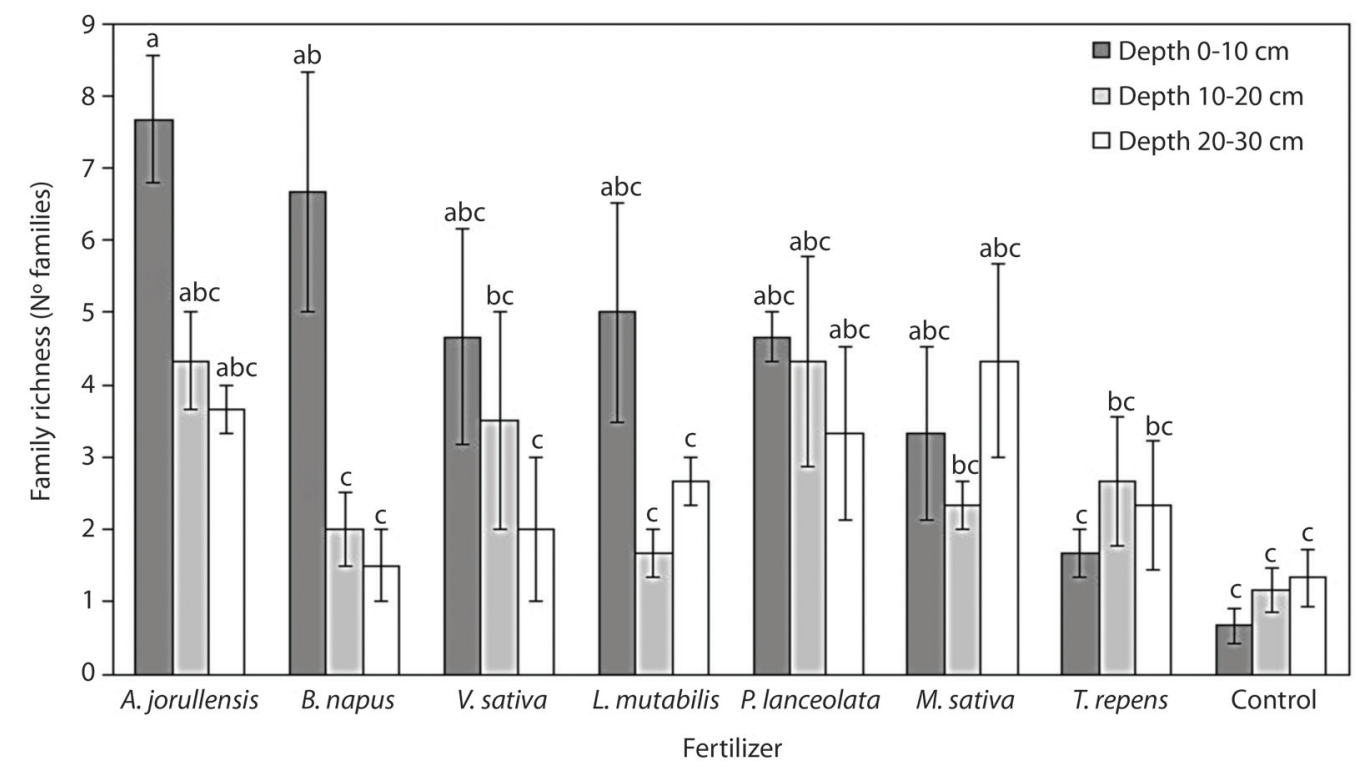

Fig. 3. Comparison of the mean family richness of soil invertebrates between each green fertilizer treatment and each soil depth at the experimental plot El Fondo in Southwestern Colombia. Vertical bars represent the standard error of the mean and different letters show significant differences according to the post-hoc Tukey test $(\mathrm{P}<0.05)$.

V. sativa-Polydesmidae, L. mutabilis-Formicidae, and T. repens-Noctuidae.

Biomass: The analysis of variance showed a significant effect of the green fertilizers $(\mathrm{F}=$ 3.4, $\mathrm{P}<0.01)$, soil depth $(\mathrm{F}=3.21, \mathrm{P}<0.05)$ and their interaction $(\mathrm{F}=2.67, \mathrm{P}<0.05)$ on the invertebrate biomass (Fig. 4). Biomass was particularly high at depth $10-20 \mathrm{~cm}$ in the Control treatment, with a mean value of 161.76 g. The treatments with lower biomass were $A$. jorullensis and $T$. repens, with mean values of $1.92 \mathrm{~g}$ and $0.69 \mathrm{~g}$, respectively. In general, biomass tended to decrease in those treatments with higher invertebrate richness and abundance (Fig. 5). 


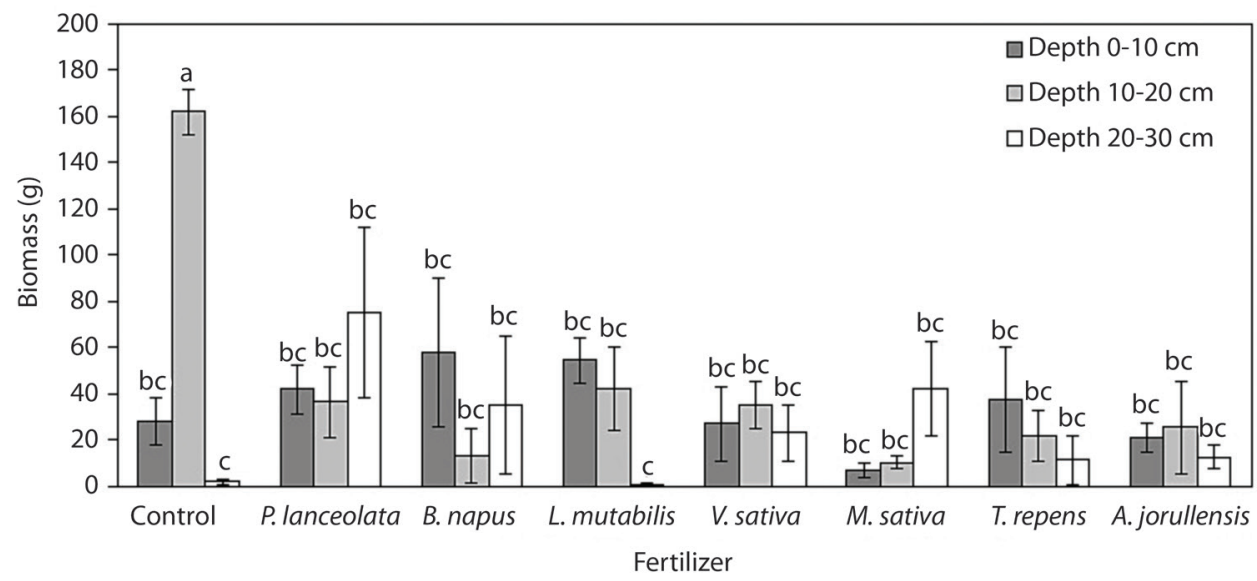

Fig. 4. Comparison of the mean biomass of soil invertebrates between each treatment and each soil depth at the experimental plot El Fondo in Southwestern Colombia. Vertical bars represent the standard error of the mean and different letters show significant differences according to the post-hoc Tukey test $(\mathrm{P}<0.05)$.

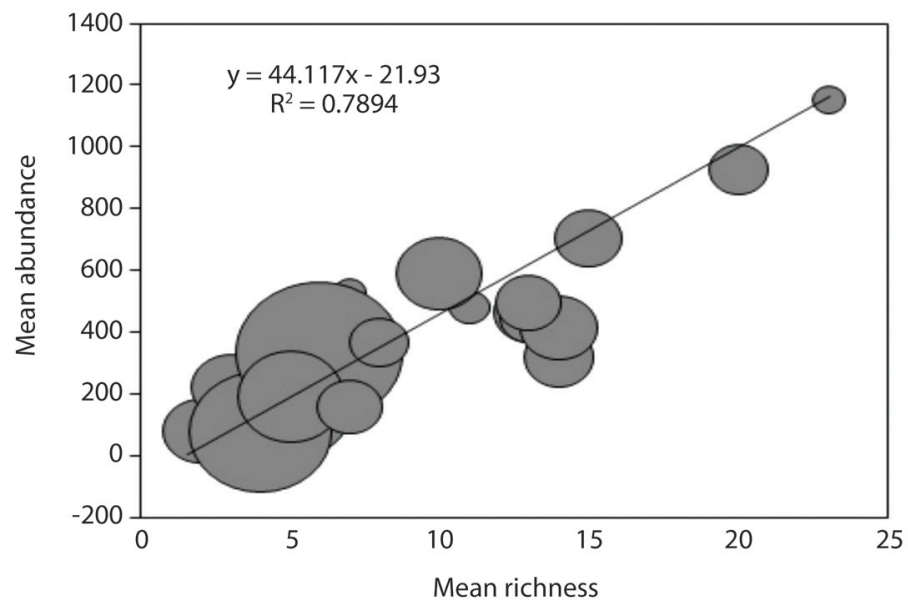

Fig. 5. Relationship between family richness and the abundance of individuals in the 24 soil cores in the experimental plot "El Fondo" in Southwestern Colombia. The line represents a type II linear regression model (Reduced Major Axis), with parameters 44.11 (slope) and -21.9 (intercept), and with $\mathrm{R}^{2}=0.78,(\mathrm{P}<0.001)$. The size of the points represents a proportional measure of the biomass, standardized to the abundance registered of each core.

Diversity: The analysis of variance for the Shannon index showed a significant effect of the green fertilizers $(\mathrm{F}=2.67, \mathrm{P}<0.01)$ and soil depth $(\mathrm{F}=4.34, \mathrm{P}<0.05)$. For the Simpson index there was only a significant effect of the green fertilizers $(\mathrm{F}=2.67, \mathrm{P}<0.05)$. The Shannon index was higher in the A. jorullensis treatment $(\mathrm{H}=1.30)$, followed by $P$. lanceolata $(\mathrm{H}=1.15)$, while the lowest value was found for the Control treatment $(\mathrm{H}=0.39)$. The highest Simpson index was found for Control $(\mathrm{D}=0.75)$ and $T$. repens $(\mathrm{D}=0.67)$, while the A. jorullensis treatment had the lowest value $(\mathrm{D}=0.39)$ (Fig. 6). These results show that the application of green fertilizers reduced the dominance of few families (Lumbricidae in the case of Control), but increased the number of families present in the soil, as well as the prerational evenness of abundance among them. This last was the case of A. jorullensis 
TABLE 1

Abundance of invertebrate individuals by Family in each green fertilizer treatment per $\mathrm{m}^{2}$ at the experimental plot El Fondo in Southwestern Colombia

\begin{tabular}{|c|c|c|c|c|c|c|c|c|c|c|}
\hline \multirow{2}{*}{$\begin{array}{c}\text { Functional } \\
\text { group }\end{array}$} & \multirow{2}{*}{ Families } & \multicolumn{8}{|c|}{ Fertilizer } & \multirow{2}{*}{ Total } \\
\hline & & Control & V. sativa & P. lanceolata & M. sativa & T. repens & B. napus & L. mutabilis & A. jorullensis & \\
\hline \multirow[t]{9}{*}{ Depredate } & Acaridae & 0 & 112 & 64 & 0 & 16 & 48 & 64 & 32 & 336 \\
\hline & Carabidae & 16 & 0 & 64 & 112 & 0 & 48 & 0 & 576 & 816 \\
\hline & Coccinellidae & 48 & 0 & 96 & 48 & 48 & 0 & 16 & 16 & 272 \\
\hline & Cryptopidae & 0 & 32 & 64 & 0 & 0 & 48 & 0 & 16 & 160 \\
\hline & Elateridae & 0 & 16 & 0 & 0 & 0 & 32 & 0 & 0 & 48 \\
\hline & Hemerobidae & 0 & 0 & 32 & 48 & 16 & 32 & 16 & 32 & 176 \\
\hline & Lycosidae & 16 & 16 & 0 & 0 & 0 & 16 & 0 & 32 & 80 \\
\hline & Nabidae & 0 & 0 & 16 & 0 & 0 & 0 & 16 & 32 & 64 \\
\hline & Vespidae & 0 & 32 & 0 & 0 & 16 & 16 & 0 & 0 & 64 \\
\hline \multirow[t]{9}{*}{ Detritivores } & Blattidae & 0 & 16 & 0 & 0 & 0 & 0 & 0 & 0 & 16 \\
\hline & Entomobryidae & 0 & 32 & 16 & 0 & 0 & 0 & 0 & 0 & 48 \\
\hline & Forficulidae & 0 & 0 & 16 & 96 & 16 & 0 & 0 & 0 & 128 \\
\hline & Gelechiidae & 0 & 0 & 16 & 0 & 0 & 0 & 0 & 0 & 16 \\
\hline & Miridae & 0 & 0 & 0 & 16 & 0 & 0 & 0 & 0 & 16 \\
\hline & Polydesmidae & 0 & 16 & 0 & 0 & 0 & 0 & 0 & 0 & 16 \\
\hline & Porcellionidae & 0 & 0 & 16 & 0 & 0 & 0 & 0 & 0 & 16 \\
\hline & Scarabaeidae & 48 & 208 & 128 & 144 & 32 & 320 & 224 & 80 & 1184 \\
\hline & Staphylinidae & 0 & 0 & 0 & 32 & 16 & 0 & 48 & 96 & 192 \\
\hline \multirow[t]{3}{*}{ Collector } & Elmidae & 0 & 0 & 16 & 16 & 16 & 0 & 0 & 48 & 96 \\
\hline & Stratyomidae & 0 & 0 & 0 & 0 & 0 & 0 & 16 & 192 & 208 \\
\hline & Tipulidae & 0 & 0 & 0 & 0 & 0 & 0 & 0 & 32 & 32 \\
\hline \multirow[t]{8}{*}{ Herbivores } & Acridoidea & 16 & 0 & 0 & 0 & 0 & 0 & 0 & 16 & 32 \\
\hline & Chrysomelidae & 0 & 0 & 0 & 80 & 16 & 0 & 0 & 0 & 96 \\
\hline & Cicadidae & 0 & 0 & 0 & 0 & 16 & 16 & 32 & 0 & 64 \\
\hline & Curculionidae & 0 & 0 & 32 & 80 & 0 & 128 & 16 & 80 & 336 \\
\hline & Noctuidae & 0 & 0 & 0 & 0 & 16 & 0 & 32 & 32 & 80 \\
\hline & Nymphalidae & 0 & 32 & 0 & 16 & 16 & 0 & 0 & 32 & 96 \\
\hline & Pentatomidae & 0 & 16 & 0 & 0 & 0 & 0 & 0 & 0 & 16 \\
\hline & Ptilodactylidae & 48 & 0 & 64 & 0 & 0 & 0 & 0 & 80 & 192 \\
\hline \multirow{6}{*}{$\begin{array}{l}\text { Soil } \\
\text { engineers }\end{array}$} & Formicidae & 0 & 0 & 176 & 368 & 48 & 16 & 288 & 0 & 896 \\
\hline & Lumbricidae & 320 & 160 & 640 & 480 & 432 & 464 & 320 & 640 & 3456 \\
\hline & Drosophilidae & 0 & 0 & 0 & 0 & 0 & 144 & 0 & 16 & 160 \\
\hline & Sp. 1 & 0 & 0 & 0 & 16 & 0 & 0 & 0 & 0 & 16 \\
\hline & Sp. 2 & 0 & 0 & 0 & 0 & 0 & 16 & 0 & 0 & 16 \\
\hline & Sp. 3 & 0 & 0 & 48 & 0 & 0 & 0 & 0 & 0 & 48 \\
\hline Total & & 512 & 688 & 1504 & 1552 & 720 & 1344 & 1088 & 2080 & 9488 \\
\hline
\end{tabular}

treatment, colonized by 20 invertebrate families at the end of the experiment (Table 1).

\section{DISCUSSION}

Among the diversity of soil invertebrates that were found in this experiment, we identified different functional groups associated with particular green fertilizers. The detritivores represented by the families of the millipedes (Polydesmidae), the woodlice (Porcellionidae) and some beetles (Scarabaeidae), were associated to the $P$. lanceolata, $M$. sativa, and $B$. napus. This association may be due to 




Fig. 6. Comparison of the mean values of diversity indices $H$ 'and $\mathrm{S}$ in each treatment and each depth in the experimental plot El Fondo in Southwestern Colombia. The values are standardized to $\mathrm{z}$ units to facilitate their observation and comparison. Vertical bars represent $95 \%$ confidence intervals.

the habitat provided by these fertilizers, with high humidity, temperature, and the ease of the plant material to be degraded and consumed. The organisms belonging to these families feed mainly on decomposing detritus, releasing nutrients and contributing to increase their availability in the soil. This helps plant growth and the storage of carbon in the soil (Mohammad, Rajasekar, \& Patil, 2017). Additionally, these organisms are sensitive to abrupt changes in humidity and temperature, so they tend to quickly disappear under stress conditions (Zerbino, 2005). This makes this group highly relevant as an ecological indicator of soil quality under agroforestry management.

A high abundance of individuals from Lumbricidae and Formicidae was associated with the A. jorullensis, $V$. sativa and B. napus fertilizers. These organisms belong to the functional group of soil engineers, linked to the improvement of the physical properties that favor the formation of aggregates, the retention of water, the gaseous exchange and the mineralization of organic matter (Lavelle, 2000; Cabrera, Robaina, \& Ponce De León, 2001; Cunha et al., 2016). The presence of these families has repercussions on the infiltration processes in the soil, since their organisms form channels that allow the movement of water. They also help the root development for different plant species (Domínguez, Aira, \& Gómez, 2009) and serve as indicators for the biological quality of soils (Cairo, 2003).

The functional group of the predators, mainly represented by earwigs and some beetles from Carabidae and Coccinellidae, indicate complex trophic networks in the invertebrate community (Gullan \& Cranston, 2000; Rousseau, Fonte, Téllez, Van Der, \& Lavelle, 2013). The high abundance of these organisms associated with the A. jorullensis and P. lanceolata treatments indicate predation functions, particularly important over those pest species usually harmful for the crops (Funichello, Costa, \& Gil, 2012). In Nariño, potato crops the most important for the economy of the Andean region- are attacked by aphids (virus vectors), who affect the seed production. However, this attack is significantly reduced by Coccinellidae organisms, which act as biological controllers («FEDEPAPA», sf).

A. jorullensis is known for having leaves with $\mathrm{C} / \mathrm{N}$ rates around 20.6, lightly lignified and nitrogen rich (Mora, 2006), which is of great benefit for the soils due to rapid decomposition and higher $\mathrm{N}$ availability for decomposer 
organisms (Wagner \& Wolf, 1998). Furthermore, A. jorullensis leaves also provide higher moisture to the soil, favoring the occurrence of organisms that decompose organic matter (Cabezas, Peña, Díaz, \& Moreno, 2008). B. napus leaves has been found to favor the phosphorous and nitrogen re-cycling, modifying the composition of soil invertebrate communities (Arévalo, 2000).

In addition, due to climatic conditions, Genoy soils maintain a relatively high humidity throughout the year, a factor that guarantees a mitigating effect on temperature changes to achieve the colonization of fauna (Lavelle \& Spain, 2001).

The higher individual's abundance and familie's richness of soil invertebrates found in depth $0-10 \mathrm{~cm}$ and is mainly explained by the reduction of the organic matter content and the oxygen at greater depths, which provide habitats and food for their development (Castro, Burbano, \& Bonillam 2007). Our results agree with Delgado, Burbano and Silva (2010), who report the highest values in abundance and species richness in the surface soil layer $(0-10 \mathrm{~cm})$. Similarly, Villalobos et al. (2000) concluded that the abundance of soil invertebrates decreases with depth. However, another possible explanation is related to the time required for the fertilizer to reach deeper soil layers, which will additionally depend on porosity, hydraulic conductivity and rates of decomposition of organic matter. Most likely, the 45 days after incorporation in our experiment were not enough to trigger ecological changes below $20 \mathrm{~cm}$.

For biomass, the results were inverse to the abundance and richness, since maximum values were found for Control, and minimum for A. jorullensis treatment. Because of the negative correlation between richness-biomass and abundance-biomass, the existence of an ecological trade-off between these variables seems to emerge. This would mean that, although green fertilizers have the capacity to promote the colonization of diverse invertebrates, the price is a decrease in the biomass. Since abundance increased with richness, it is itself not an explanation for the biomass. Our data do not allow us to properly explain this result; however, we hypothesize that it could be related to lower body sizes characteristic of those invertebrates that had a closer association for certain fertilizers. For example, in general, Tipulidae -unique under $A$. jorullensis fertilization and Stratyomidae shared only between $A$. jorullensis and L. mutabilis fertilizations have smaller mean body sizes (Hjorth-Andersen, 2015) than the invertebrates found in Control. Another hypothesis is higher competence intensity in treatments with more diversity, which implies that the available resources must be shared among more species and individuals. However, further research and data is needed to prove this hypothesis.

In general, these results allow us to highlight the big effects of the A. jorullensis and $B$. napus as green fertilizers in triggering the diversity of soil invertebrates and propose them as effective treatments to conserve soil functions in the region. Nevertheless, forthcoming studies should consider the importance of creating mixtures of different fertilizers to regulate/maintain functionality in the soil. It is also important that new studies identify specimens to the species level, since this could inform about more specific functional groups, host-fertilizer associations and the benefits for the soil.

Ethical statement: authors declare that they all agree with this publication and made significant contributions; that there is no conflict of interest of any kind; and that we followed all pertinent ethical and legal procedures and requirements. All financial sources are fully and clearly stated in the acknowledgements section. A signed document has been filed in the journal archives.

\section{ACKNOWLEDGMENTS}

We are grateful to the VIPRI (Vicerrectoría de Investigaciones y Relaciones Internacionales) of Universidad de Nariño to provide the funding for this research; to Facultad de 
Ciencias Agrícolas of Universidad de Nariño to allow the use of the laboratories; and to the local farmers in El Fondo for their help during the experiment.

\section{RESUMEN}

Efecto de fertilizantes verdes en la estructura ecológica de las comunidades de invertebrados edáficos en un suelo andisol del suroestre de Colombia. Introducción: Los fertilizantes químicos para la agricultura afectan negativamente a las comunidades de invertebrados, las cuales contribuyen al ciclaje, disponibilidad de los nutrientes y a la formación y fertilidad del suelo. Como alternativa, investigaciones previas han sugerido que los abonos verdes (tejido fresco de plantas) son efectivos para conservar la fertilidad del suelo, posiblemente sin afectar los invertebrados. Objetivo: Evaluar como la aplicación de abonos verdes al suelo afecta cuantitativamente estas propiedades en una comunidad de macrofauna edáfica de un andisol al suroccidente de Colombia. Métodos: El follaje fresco de siete especies de plantas sembradas y cultivadas localmente durante marzo 2018 fue utilizado como abono verde, el cual fue incorporado y mezclado con el suelo superficial en 24 subparcelas experimentales. Después de 45 días de aplicar los abonos, se midió la abundancia, riqueza, biomasa y diversidad de la comunidad de invertebrados. Resultados: En comparación a un tratamiento testigo la riqueza y abundancia de invertebrados fue 14 veces más alta en tratamientos con $A$. jorullensis y B. napus, y cinco veces más alta en tratamientos con $V$. sativa, L. mutabilis, P. lanceolata y $M$. sativa. Los índices de diversidad mostraron un cambio desde una dominancia por una o pocas familias de invertebrados en el testigo, a una alta diversidad y equitatividad en los tratamientos con A. jorullensis, $P$. lanceolata y $M$. sativa. La biomasa estuvo correlacionada negativamente con la riqueza y la abundancia, sugiriendo un posible trade-off, en este sentido se sugiere que sea estudiada en futuras investigaciones. Conclusiones: En general, estos resultados demuestran que la aplicación de abonos verdes en estos suelos andinos puede mejorar significativamente la presencia de macroinvertebrados en el suelo.

Palabras clave: suelo, abonos verdes, macrofauna, diversidad, abundancia, riqueza.

\section{REFERENCES}

Abi-saab, R. (2012). Evaluación de la calidad del suelo, en el sistema productivo orgánico La Estancia, Madrid, Cundinamarca (Tesis de pregrado). Pontificia Universidad Javeriana, Bogotá.

Agrosemillas | Importadora y comercializadora en Medellín. (s.f.). Semillas de calidad. Recuperado de https:// agrosemillas.com.co
Anderson, J., \& Ingram, J. (1993). Tropical soil biology and fertility. A handbook of methods. Wallingford, UK: Editorial CABI Publishing.

Arévalo, E. (2000). Cultivar sin arar. Labranza mínima y siembra directa. Bogotá, Colombia: Proyecto de Conservación de Suelo y Agua en la Zona Andina - Proyecto Checua. Recuperado de https://www.rds. org.co/aa/img_upload/30af8836e18ffedc2f0c153736 01ed59/labranza.PDF

Bautista, D., Chavarro, R., Cáceres, J., \& Buitrago, S. (2017). Efecto de la fertilización edáfica en el crecimiento y desarrollo de Phaseolus vulgaris cv. ICA CERINZA. Revista Colombiana de Ciencias Hortícolas, 11(1), 122-132.

Blum, W. (2000). Methods for Assessment of Soil Degradation. Advances in soil Science. Boca Ratón, Florida, USA: Editorial CRC Press.

Cabezas, M., Peña, F., Díaz, C., \& Moreno, A. (2008). Dosel de tres especies forestales y su relación con la adaptación a suelos degradados por erosión. U.D.C.A., 11(2), 175-185.

Cabrera, G., Robaina, N., \& Ponce De León, D. (2001). Composición funcional de la macrofauna edáfica en cuatro usos de la tierra en las provincias de Artemisa y Mayabeque, Cuba. Pastos y Forrajes, 34(3), 331-346.

Cairo, P. (2003). La Fertilidad Física del Suelo y la Agricultura Orgánica en el Trópico. Revista Ciencias Técnicas Agropecuarias, 19(1), 145-163.

Carreón, S., \& Martínez, M. (2016). Abonos Verdes. Recuperado de http://www.sagarpa.mx/desarrolloRural/ Documents/fichasCOUSSA/Abonos\%20Verdes.pdf

Castro, H., Burbano, H., \& Bonilla, C. (2007). Abundancia y biomasa de organismos edáficos en tres unos de terreno en el altiplano de Pasto, Colombia. Acta Agronómica, 56(3), 127-130.

Chao, A., Colwell, R., Lin, C., \& Gotelli, N. (2009). Sufficient sampling for asymptotic minimum species richness estimators. Ecology, 90(4), 1125-1133.

Climate-Data.Org. (2018). Datos climáticos mundiales. Clima Genoy. Recuperado de https://es.climate-data. org/america-del-sur/colombia/narino/genoy-465490

Colwell, R. (2006). Estimates: Statistical Estimation of Species Richness and Shared Species from Samples (Version 8). Retrieved from http://viceroy.eeb.uconn. edu/estimates

Culliney, T. (2013). Role of Arthropods in Maintaining Soil Fertility. Agriculture, 48(3), 629-659. DOI: 0.3390/ agriculture 3040629

Cunha, L., Brown, G., Stanton, D., Da Silva, E., Hansel, F., Jorge, G., ... Red Kille, P. (2016). Soil animals and 
pedogenesis: the role of earthworms in anthropogenic soils. Soil Science, 181(3/4), 110-125.

Delgado, G., Burbano, A., \& Silva, A. (2010). Evaluación de la macrofauna del suelo asociada a diferentes sistemas con café Coffea arabiga L. Revista de Ciencias Agrícolas, 28(1), 91-96.

Domínguez, J., Aira, M., \& Gómez, M. (2009). El papel de las lombrices de tierra en la descomposición de la materia orgánica y el ciclo de nutrientes. Ecosistemas, 18(2), 20-31.

Doreste, E. (1984). Acarología. San José, Costa Rica: Instituto Interamericano de Cooperación para la Agricultura IICA.

FAO. Organización de las Naciones Unidas para la Agricultura y la Alimentación. (2015). Suelos y biodiversidad. Recuperado de http://www.fao.org/3/a-i4551s. pdf

Fauchald, K. (1977). The polychaete worms. Definitions and keys to the orders, families and genera. Natural History Museum of Los Angeles County. Science Series, 28, 1-188.

FEDEPAPA. (s. f.). Manejo integrado de plagas y enfermedades en el cultivo de papa. Recuperado de https:// fedepapa.com

Funichello, M., Costa, L., \& Gil, O. (2012). Aspectos biológicos de Cycloneda sanguinea (Coleoptera: Coccinellidae) alimentadas con pulgones criados en algodón transgénico Bollgard I. Revista Colombiana de Entomología, 38(1), 156-161.

Gullan, P., \& Cranston, P. (2000). The Insects: An Outline of Entomology. Retrieved from http://www. programamoscamed.mx/EIS/biblioteca/libros/libros/ Gullan\%20P.J.,\%20Cranston\%20P.\%20The\%20 Insects..\%20line\%20of\%20Entomology\%202010_. pdf

Gupta, S., \& Malik, V. (1996). Ecología del suelo y sostenibilidad. Journal of Tropical Ecology, 37, 43-55.

Guzmán, G., \& Alonso, A. (2008). Buenas prácticas en producción ecológica. Uso de abonos verdes. Recuperado de http://www.agroecologia.net/recursos/ publicaciones/bppe/Uso de Abonos Verdes tcm7187426.pdf

Hjorth-Andersen, M. (2015). Clase insecta. Orden Díptera. IDEA@-SEA, 65, 1-22.

Holdridge, L. (1966). Life zone ecology. Retrieved from http://reddcr.go.cr/sites/default/files/centro-de-documentacion/holdridge_1966_-_life_zone_ecology.pdf

IDEAM. (2015). Protocolo para la identificación y evaluación de la degradación de suelos por erosión.
Recuperado de http://documentacion.ideam.gov.co/ openbiblio/bvirtual/023647/Protocolo-erosion.pdf

Instituto Geográfico Agustín Codazzi. IGAC. (2004). Estudio general de los suelos y zonificación de tierras del departamento de Nariño. Recuperado de https:/www.academia.edu/38164592/Estudio_General_de_suelos_y_zonificaci $\% \mathrm{C} 3 \% \mathrm{~B} 3 \mathrm{n}$ _de tierras del_departamento_de_Nari\%C3\%B1o

Julca, A., Meneses, L., Blas, R., \& Bello, S. (2006), La materia orgánica, importancia y experiencia de su uso en la agricultura. Idesia, 24(1), 49-61.

Labrador, M. (2001). La materia orgánica en los agroecosistemas. Madrid, España: Grupo Mundi- Prensa.

Lavelle, P. (2000). Ecological challenges for soil science. Soil Science, 165(1), 73-86. DOI: 10.1097 / 00010694-200001000-00009

Lavelle, P., \& Spain, A. (2001). Soil Ecology. New York, USA: Editorial Springer Science \& Business.

Mäder, P., Fliessbach, A., Dubois, D., Gunst, L., Fred, P., \& Niggli, U. (2002). Fertility and biodiversity in organic farming. Science, 296(5573), 1694-1697. DOI: $10.1126 /$ science. 1071148

Mohammad, S., Rajasekar, B., \& Patil, R. (2017). Estimation of Soil Macro Arthropods in Cotton Intercropped with Groundnut under Organic, Integrated and Conventional Farming Systems. IJCMAS, 6(6), 2424-2429.

Mora, J. (2006). La actividad microbiana: un indicador integral de la calidad del suelo. Revista Luna Azul, $2,1-6$.

Morán, Y., Portillo, M., Burbano, H., Vélez, J., Ruiz, H., \& Navia, J. (2012). Efecto de la incorporación de hojarasca de especies arbóreas sobre el $\mathrm{co} 2, \mathrm{pH}$ y fósforo en un suelo Vitric Haplustand. Revista de Ciencias Agrícolas, 29(2), 16-25.

Moreno, C. (2001). Métodos para medir la biodiversidad. Recuperado de http://entomologia.rediris.es/sea/manytes/metodos.pdf

Prager, M., Sanclemente, O., Sánchez, M., Gallego, J., \& Sánchez, Á. (2012). Abonos verdes: Tecnológia para el manejo agroecológico de los cultivos. Agroecología, 7, 53-62.

Rousseau, L., Fonte, S., Téllez, O., Van Der, H., \& Lavelle, P., (2013). Soil macrofauna as indicators of soil quality and land use impacts in smallholder agroecosystems of western Nicaragua. Ecological Indicators, 27, 71-82. DOI: 10.1016/j.ecolind.2012.11.020

RStudio Team (2017). RStudio: Integrated Development for R. Retrieved from http://www.rstudio.com 
Sokal, R., \& Rohlf, F. (1995). Biometry. The principles and practice of statistics in biological. New York, USA: Editorial Peter Marshall.

Stork, N., \& Eggleton, P. (1992). Invertebrates as determinants and indicators of soil quality. American Journal of Alternative Agriculture, 7(1/2), 38-47.

Triplehorn, C., \& Johnson, N. (2004). Borror and DeLong's Introduction to the Study of Insects. Belmont, USA: Editorial Thomson Brooks/Cole.

Villalobos, F., Ortiz, P., Moreno, C., Pavón, N., Hernández, H., Bello, J., \& Montiel, S. (2000). Patrones de la macrofauna edáfica en un cultivo de Zea maiz durante la fase postcosecha en "La Mancha", Veracruz, México. Acta Zoológica Mexicana, 80, 167-183.

Wagner, G., \& Wolf, D. (1998). Carbon transformations and soil organic matter formation. In D. Silvia, J. Furhman, P. Haretel, \& D. Zuberer (Eds.), Principles and applications of soil microbiology (pp. 285-319). Upper Saddle River, New Jersey: Editorial Pearson Prentice Hall.

Zerbino, M. (2005). Evaluación de la densidad, biomasa y diversidad de la macrofauna del suelo en diferentes sistemas de producción (Tesis de maestría). Universidad de la República, Montevideo, Uruguay. 